\title{
Effect of Honey Variation on Blood Glucose Level in Pregnant Wistar Rats (Rattus norvegicus)
}

\author{
Syarifuddin Syarifuddin, Veny Hadju*, Rahayu Inriasari \\ Department of Nutrition, Faculty of Public Health, Hasanuddin University, Makassar, Indonesia
}

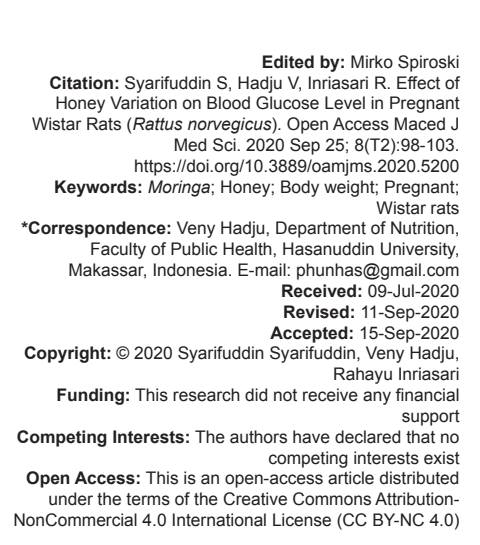

\section{Introduction}

The problem of nutritional status in infancy and toddlers is closely related to nutrition problems in pregnant women. The condition of pregnant women provides a very large influence on the growth and development of the baby in the womb. For this reason, the government's efforts to overcome this problem have been focused since the fetus was in the womb or when the mother was pregnant. This program is known as a thousand early days of life and has been established through Presidential Regulation no. 42 of 2013 concerning the National Movement for the Acceleration of Nutrition Improvement [1].

Micronutrients have been shown to affect fertility, embryogenesis, and placentation. Micronutrient supplementation has been widely used to prevent abnormalities in pregnancy outcomes. Malnutrition in pregnant women can cause pregnancy complications, low-birth weight babies, increase the risk of degenerative diseases such as hypertension, coronary heart disease, and type 2 diabetes [2].

Increased insulin resistance in pregnant women increases to $80 \%$ in the second and third trimester of pregnancy. This problem is increasing along with increasing gestational age in pregnant women, causing an increase in blood glucose levels, this if not addressed will increase the risk of gestational diabetes mellitus that often occurs in pregnant women. According to data from the American Diabetes Association in 2000 , about $7 \%$ of gestational diabetes mellitus occurs during pregnancy each year, where the prevalence of gestational diabetes mellitus varies between $1 \%$ and $14 \%$. In Indonesia, the prevalence of gestational diabetes mellitus is in the range of $1.9-3.6 \%$ [3].

One good source of nutrients is Moringa leaves and honey (Moringa oleifera), Moringa is known worldwide as a nutritious plant and the World Health Organization (WHO) has introduced Moringa as an alternative food to overcome nutritional problems (malnutrition) while honey is known to be a one of the foods that have been used for generations as a traditional medicine. In Africa and Asia Moringa leaves are recommended as a nutrient-rich supplement for breastfeeding mothers and children during infancy [4].

Research on the nutritional content of Moringa leaves has been widely stated, one of them is research, stating that in other studies show that in 100 grams of fresh Moringa leaves have a water content of $94.01 \%$, $22.7 \%$ protein, $4.65 \%$ fat, 51 carbohydrates, $66 \%$, 7.92 fiber, and $0 \%$ energy [5]. Moringa leaves contain 
phenols in large quantities which are known as antidote to Moringa leaves that have been extracted are $1.6 \%$ [6] while honey is known to have many health benefits. The content of nutrients in honey is carbohydrates, proteins, amino acids, vitamins, and minerals. Vitamins contained in honey include Vitamin B1, B2, B3, B6, $\mathrm{C}, \mathrm{A}$, and $\mathrm{E}$, while for the mineral content such as $\mathrm{Na}$, $\mathrm{Ca}, \mathrm{K}, \mathrm{Mg}, \mathrm{Cl}, \mathrm{Fe}, \mathrm{Zn}$, and others, honey also contains flavonoids honey is believed to be beneficial for health because of the antioxidant ability of honey [7].

In a study conducted by Odedele et al. using Moringa seed extract given to diabetic pregnant mice showed that giving $M$. oleifera seed extract in pregnant mice with diabetes could reduce blood glucose levels in pregnant mice and play a role in reducing fetal morbidity and mortality [8]. In addition, studies have shown that giving honey together with Moringa leaf extract in pregnant women has been proven to prevent DNA damage [9].

Honey and Moringa ( $M$. oleifera) are food ingredients that are commonly found in areas that have great potential to become herbal supplement ingredients. Moringa honey products are needed as a supplement for pregnant women for the needs of macro- and micronutrients. To increase the nutritional content of honey, honey-producing bees are usually given additional food in the form of sugar water mixed with other ingredients that contain the desired nutrition [10].

Based on data on the nutritional content of Moringa and honey and their health benefits, especially pregnant women researchers are interested in seeing the effects of weight gain in white Wistar rats (Rattus norvegicus) pregnant women given Moringa honey, honey plus Moringa, and natural honey.

\section{Materials and Methods}

The research process in the experimental animals was carried out at the Laboratory of Immunology and Molecular Biology, Microbiology Section of the Faculty of Medicine, Universitas Hasanuddin. This research is a quantitative research with experimental lab research type. With a completely randomized pretest and post-test controlled (RAL) research design.

The population of this study was female Wistar white rats aged 10-12 weeks weighing 110-150 grams while the samples in this study were pregnant female Wistar strain rats that met the study inclusion criteria. Animal samples were divided into four groups with each group consisting of six pregnant Wistar rats, namely, the control group, natural honey, honey plus Moringa, and Moringa honey with honey doses of $0.27 \mathrm{ml} / \mathrm{rat} /$ day given orally for 20 days of pregnancy by measuring blood glucose levels in early pregnancy and late pregnancy.
The data collected in this study are primary data obtained from laboratory results in the form of test results of nutrient and phytochemical content of honey, Moringa, and Moringa honey as well as the results of the treatment of experimental animals.

Data processing was performed using a computer with the SPSS 20 program by comparing measurement results before and after treatment using paired t-test/Wilcoxon test and one-way ANOVA/ Kruskal-Walls test to see the results of the comparison between groups presented in tabular and graphic form with narrative with a significance value of $p<0.05$.

\section{Results}

Blood glucose in this study was measured using a nescometer. Measurements were taken at 0 days before the intervention (pre-test), 2 weeks after the intervention and at the end of 20 days (post-test).

Figure 1 shows the data on the state of blood glucose in pregnant Wistar rats. The blood glucose in the lowest control group was found in rat $\mathrm{C}$ with a blood glucose level of $73 \mathrm{mg} / \mathrm{dL}$ and the highest blood glucose level was found in rat $B$ with a glucose level of $177 \mathrm{mg} / \mathrm{dL}$. In the honey group, the lowest blood glucose level was found in mice $C$ with blood glucose levels of $93 \mathrm{mg} / \mathrm{dL}$ and the highest blood glucose levels were found in mice B with blood glucose levels of $139 \mathrm{mg} / \mathrm{dL}$. In the honey plus Moringa group, the lowest blood glucose level was found in rat $D$ with blood glucose level of $63 \mathrm{mg} / \mathrm{dL}$ and the highest blood glucose level was found in rat $A$ with blood glucose level of $131 \mathrm{mg} / \mathrm{dL}$. In the Moringa honey group, the lowest blood glucose level was found in rat $F$ with blood glucose level of $105 \mathrm{mg} / \mathrm{dL}$ and the highest blood glucose level was found in rat $\mathrm{C}$ with blood glucose level $128 \mathrm{mg} / \mathrm{dL}$.



Figure 1: Description of blood glucose levels in pregnant Wistar rats

At 2 weeks gestation, the lowest blood glucose level in the control group was found in rat $E$ with a blood glucose level of $98 \mathrm{mg} / \mathrm{dL}$ and the highest blood glucose level was found in rat B with a blood glucose level of $124 \mathrm{mg} / \mathrm{dL}$. In the honey group, the lowest blood glucose level was found in $F$ rat with blood glucose level of $79 \mathrm{mg} / \mathrm{dL}$ and the highest blood glucose level was in C mouse with blood glucose level of $101 \mathrm{mg} / \mathrm{dL}$, 
in the honey group plus Moringa the lowest blood glucose level in pregnant mice found in rat $E$ with a blood glucose level of $51 \mathrm{mg} / \mathrm{dL}$ and the highest blood glucose level found in rat $B$ with a blood glucose level of $126 \mathrm{mg} / \mathrm{dL}$, while in the Moringa honey group the lowest blood glucose level was found in rat $\mathrm{C}$ with a blood glucose level of $66 \mathrm{mg} / \mathrm{dL}$ and the highest blood glucose level was found in rat $A$ with blood glucose level of $129 \mathrm{mg} / \mathrm{dL}$ (Figure 1).

At the end of pregnancy at the age of 20 days, the lowest control blood glucose level was found in rat $C$ with a blood glucose level of $69 \mathrm{mg} / \mathrm{dL}$ and the highest blood glucose level was in mouse $A$ with a blood glucose level of $90 \mathrm{mg} / \mathrm{dL}$, in the honey group, the lowest blood glucose level was found in rat $F$ with blood glucose level of $74 \mathrm{mg} / \mathrm{dL}$ and the highest blood glucose level was in rat $D$ with blood glucose level of $90 \mathrm{mg} / \mathrm{dL}$, in the honey group plus Moringa the lowest blood glucose level was found in rat $D$ with blood glucose levels of $58 \mathrm{mg} / \mathrm{dL}$ and the highest blood glucose levels were found in mice $B$ with blood glucose levels of $89 \mathrm{mg} / \mathrm{dL}$, whereas in the Moringa honey group the lowest blood glucose levels were found in mice B with blood glucose levels of $62 \mathrm{mg} /$ $\mathrm{dL}$ and the highest blood glucose levels were found in rat $D$ with a blood glucose level of $80 \mathrm{mg} / \mathrm{dL}$ (Figure 1).

In Table 1, the state of blood glucose levels in pregnant Wistar rats in early pregnancy showed the results of paired T-test in the control group that there was a decrease in blood glucose levels with an average initial blood glucose of $115.67 \pm 34.95$ at the end of pregnancy the mean reduction in blood glucose levels of pregnant rats was $82.33 \pm 8.98$ and showed a significant decrease with a $p$ value of $0.045<0.05$. The honey group was a decrease in mean blood glucose levels of pregnant mice with a mean initial blood glucose level of $119.00 \pm 19.55$ indicating a decrease in mean blood glucose levels at the end of pregnancy with a mean value of $83.83 \pm 6.67$ and showing a significant decrease with a $p$ value of $0.002<0.05$ at the end of pregnancy.

In the honey plus Moringa group also showed a decrease in blood glucose levels in pregnant Wistar rats with an average initial blood glucose of $105.50 \pm 24.39$ experienced a significant decrease in late gestational age with mean blood glucose levels in pregnant Wistar mice to $73.17 \pm 10.92$ with a $p$ value of $0.008<0.05$. In the Moringa honey group also showed a significant decrease in blood glucose levels in Wistar rats with an average initial blood glucose level of $116.50 \pm 8.89$ at the end of pregnancy mean blood glucose levels in pregnant Wistar rats showed a significant decrease to $73.00 \pm 6.45$ with a $p$ value of $0.000<0.05$ (Table 1).
Meanwhile, the one-way ANOVA test showed no significant difference in decrease in blood glucose levels between treatment groups with a $p=0.774>0.05$ in early pregnancy. At the end of pregnancy also showed a decrease in blood glucose levels that were not significant between groups with a $p=0.065>0.05$. In the delta test results, the mean difference in blood glucose levels early in pregnancy and in the end of pregnancy pregnant Wistar rats showed the mean difference in the reduction of initial and final blood glucose levels in the control group by $33.33 \pm 30.82$, in the honey group by $35.17 \pm 15.34$, in the honey plus Moringa group by $32.33 \pm 18.53$, and in the Moringa honey group by $43.50 \pm 10.91$ with a significance value of $0.771>0.05$ which means that there was no difference in the decrease in blood glucose levels between groups in pregnant Wistar rats (Table.1).

Even though statistically did not show a significant difference in the final blood glucose level of pregnant Wistar rats, $p=0.065$ indicates there is a tendency that leads to significant collar or significant borderline within acceptable limits; therefore, it will proceed to the post hoc LSD test (Table 1).

Based on Table 2, there is a significant value of final blood glucose levels in the honey group with honey plus Moringa with a $p=0.041$ and between the honey group with Moringa honey with a $p$ value of 0.038 while in the control group, honey, honey plus Moringa, and Moringa honey are in a significant borderline value, whereas in the honey plus Moringa and Moringa honey groups did not show significant differences in final blood glucose levels.

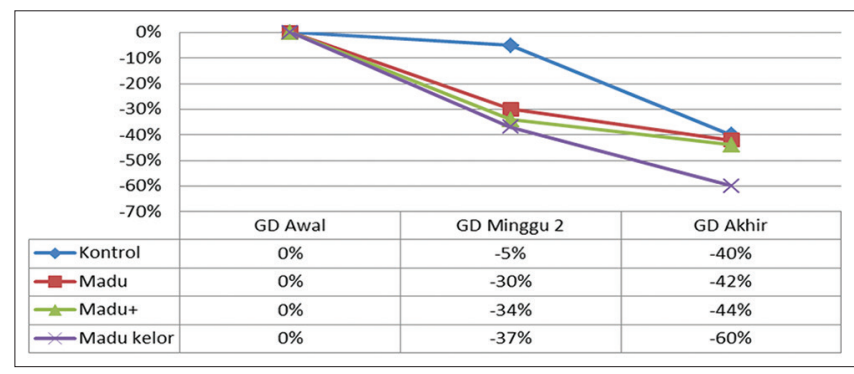

Figure 2: Percent graph average decreased blood glucose levels of pregnant Wistar rats

Figure 2 shows that the blood glucose levels of all pregnant Wistar rats decreased at 2 weeks and the end of pregnancy, where at the end of pregnancy in the Moringa honey group had the highest average reduction in blood glucose levels by $60 \%$, the honey group plus Moringa with a decrease of $44 \%$, the honey group by $42 \%$ and the lowest percent average decrease in blood glucose levels in the control group by $40 \%$.

Table 1: Analysis of blood glucose levels in pregnant Wistar rats early in pregnancy and late in pregnancy

\begin{tabular}{|c|c|c|c|c|c|}
\hline \multirow[t]{3}{*}{ Variable } & \multicolumn{4}{|l|}{ Kelompok } & \multirow[t]{3}{*}{$\mathrm{p}^{* *}$} \\
\hline & Kontrol & Madu & Madu + Kelor & Madu Kelor & \\
\hline & Mean \pm SD & Mean \pm SD & Mean \pm SD & Mean \pm SD & \\
\hline GD awal & $115.67 \pm 34.95$ & $119.00 \pm 19.55$ & $105.50 \pm 24.39$ & $116.50 \pm 8.89$ & 0.774 \\
\hline GD akhir & $82.33 \pm 8.98$ & $83.83 \pm 6.67$ & $73.17 \pm 10.92$ & $73.00 \pm 6.45$ & 0.065 \\
\hline $\mathrm{p}^{*}$ & 0.045 & 0.002 & 0.008 & 0.000 & \\
\hline mean selisih GD awal dan GD akhir & $33.33 \pm 30.82$ & $35.17 \pm 15.34$ & $32.33 \pm 18.53$ & $43.50 \pm 10.91$ & 0.771 \\
\hline
\end{tabular}


Table 2: LSD test blood glucose levels in pregnant wistar rats late in pregnancy

\begin{tabular}{lllll}
\hline Kelompok Perlakuan & \multicolumn{3}{l}{ Kelompok perlakuan } & \\
\cline { 2 - 5 } & Kontrol & Madu & Madu+Kelor & Madu Kelor \\
\cline { 2 - 5 } & Nilai Sig & Nilai Sig & Nilai Sig & Nilai Sig \\
\hline Kontrol & & 0.762 & 0.075 & 0.070 \\
Madu & 0.762 & & 0.041 & 0.038 \\
Madu+Kelor & 0.075 & 0.041 & & 0.973 \\
Madu Kelor & 0.070 & 0.038 & 0.973 & \\
\hline
\end{tabular}

\section{Discussion}

The study showed GD levels determined a significant decrease in the final group of the study, but the decrease in GD levels between groups did not show a significant difference at the end of the study.

Pregnancy is one of the factors that can increase blood glucose levels. During pregnancy, physiological changes occur in pregnant women, namely, increased production of certain hormones such as $\mathrm{hPL}$, estrogen, progesterone, cortisol, and prolactin. These hormones can cause insulin resistance, which results in high blood glucose levels while insulin levels also remain high [11].

During early pregnancy, there are anabolic conditions associated with hyperphagia and accumulation of body fat. Conversely, during late pregnancy there are catabolic conditions associated with insulin resistance where not only glucose but also free-fatty acids and ketone bodies can function as important sources of energetic substrates during fasting conditions [12], [13]. During pregnancy, there are two main metabolic problems. First, there is the possibility of gestational diabetes where the level of insulin secretion cannot overcome insulin resistance that occurs at the end of pregnancy. Second, there is an increased tendency for hypoglycemia that occurs not only in humans [14] but also mice [15].

Initial blood glucose levels in pregnant Wistar rats showed that there were mice in the control group who had diabetes with blood glucose levels of $177 \mathrm{mg} / \mathrm{dL}$ and in the honey group there were mice that had prediabetes with blood glucose levels of 138 and $139 \mathrm{mg} / \mathrm{dL}$, this classification was based on data criteria for normal rat blood glucose levels are in the range of $50-135 \mathrm{mg} / \mathrm{dL}$, prediabetes is $136-149 \mathrm{mg} / \mathrm{dL}$, and diabetes $\geq 150 \mathrm{mg} / \mathrm{dL}$ [16]. The state of high blood glucose levels is thought to be due to the treatment when taking blood in Wistar rats through the tail which must be repeatedly pierced so that blood can be drawn and measured. In this study, the results showed that there was a decrease in blood glucose levels in pregnant Wistar rats in early pregnancy to the end of pregnancy in both the control group and the intervention group for significant honey variations while in the one-way ANOVA test results showed that there was no significant difference in decreased blood glucose levels in control pregnant Wistar rats and honey variation intervention groups. This is in line with several reports which show that during late pregnancy there is an increasing tendency for hypoglycemia in not only mice [15] but also humans [14].

Although the results showed no significant difference in the decrease in blood glucose levels in pregnant Wistar rats with an average percent decrease in blood glucose levels of all groups by $46 \%$ at the end of pregnancy, the average reduction in blood glucose levels in the intervention group honey variation was better than in the control group, where the average percent decrease in blood glucose levels in the control group was around $40 \%, 42 \%$ honey group, $44 \%$ honey plus Moringa, and Moringa honey $60 \%$.

In a study conducted by Odedele et al. using Moringa seed extract given to diabetic pregnant mice showed that giving $M$. oleifera seed extract in pregnant mice with diabetes can reduce blood glucose levels in pregnant mice [8], in other studies have shown that consumption of metformin combined with honey is more effective at lowering serum glucose than only consuming metformin alone, as well as consumption of glibenclamide combined with honey is more effective at lowering serum glucose than only consuming glibenclamide alone [17]. Other results show that stevia and honey can reduce blood glucose levels [18].

Laboratory test results show that honey plus Moringa and Moringa honey contains antioxidants, flavonoids, polyphenols, Vitamin C, and carbohydrates. The content of honey is thought to have an important role in reducing blood glucose levels in pregnant Wistar rats.

Honey is a sweet liquid because it is dominated by carbohydrates in the form of fructose and glucose [7]. Based on laboratory test results the carbohydrate content of Moringa honey is $72.17 \%$ and in honey plus Moringa is $56.56 \%$, this means that the sugar content in Moringa honey is higher than honey plus Moringa, carbohydrates are an energy source in honey which is dominated by fructose and glucose. This fructose content enters the cell, starting during the absorption process of the fructose content by the intestinal wall. In the apical membrane of the intestinal epithelium, there are two transporters, namely, sodiumglucose transporter (SGLUT1) which is a glucose and galactose transporter and glucose transporter 5 ' (GLUT 5) which is a fructose transporter. Fructose is transported from the intestinal lumen to epithelial cells through GLUT 5 by simple diffusion due to differences in concentration, from high to low concentrations. GLUT 5 has a high affinity for fructose. Fructose does not need insulin mediators to enter the cell [19].

In addition to fructose content in Moringa honey, Moringa honey also contains flavonoids which act as antioxidants. From the test results, the antioxidant content of Moringa honey is $130.60 \mathrm{ppm}$ 
with a flavonoid content of $0.028 \mathrm{ppm}$. The ability of flavonoids as antioxidants can reduce oxidative stress and reduce the reactive oxygen species which cause a protective effect against pancreatic beta cells and increase insulin sensitivity [20]. Besides flavonoids also have the ability to inhibit GLUT 2 in intestinal a mucosa so that it can reduce glucose absorption, resulting in a reduction in the absorption of glucose and fructose from the intestine so that blood glucose levels fall [21].

In addition to flavonoids, other content of Moringa honey which acts as an antioxidant is polyphenols, the test results of polyphenol content in Moringa honey by $0.13 \%$, in honey plus Moringa by $0.02 \%$. Some previous researchers prove that the antioxidants of green tea polyphenols can reduce oxidative stress by preventing a chain reaction of converting superoxide to hydrogen superoxide by donating hydrogen atoms from the aromatic hydroxyl $(-\mathrm{OH})$ polyphenol group to bind free radicals and remove them from the body through the excretion system [22], [23]. The role of polyphenols as antioxidants is thought to protect pancreatic $\beta$ cells from the toxic effects of free radicals produced under chronic hyperglycemia. According to Kaneto [24], administration of antioxidants can increase pancreatic $\beta$ cell mass and maintain insulin content in it.

In cells that have insulin receptors (muscle cells, adipose cells, and liver cells), binding of free radicals will increase insulin signaling in intracellular GLUT 4 translocation to cell membranes so that it can take glucose from the blood. In general, a decrease in oxidative stress can reduce insulin resistance and inhibits pancreatic $\beta$ cell damage. Thus, the polyphenols in Moringa honey are indicated to be able to withstand the risk of disease increasing blood glucose levels in pregnant mice [24], [25], [26].

As with the effect of weight gain, a decrease in blood glucose levels in pregnant Wistar rats is also thought to be strong due to the effects of Moringa leaves which in the Moringa test contain Vitamins A, C, and E, flavonoids polyphenols which act as powerful antioxidants [27]. Polyphenol antioxidant content as already explained that polyphenol antioxidants by donating hydrogen atoms from the aromatic hydroxyl group $(-\mathrm{OH})$ polyphenols to bind to free radicals and remove them from the body through the excretion system [22], [23].

\section{Recommendation}

All study groups experienced a significant decrease in GD but the decrease did not differ significantly. However, the decrease in GD in the intervention group of Moringa honey is better than in other groups, this is due to the nutritional content of Moringa honey in the form of polyphenols, flavonoids, and Vitamin C which acts as an antioxidant as well as the main energy content in Moringa honey which is dominated by more fructose easily metabolized in the body so that it can reduce GD. Moringa honey in the future so that it can be used as a supplement for pregnant women to control GD levels in pregnant women.

\section{Conclusion}

It shows that honey variation has the effect of controlling blood glucose levels during pregnancy.

\section{References}

1. Kemenkes RI. Peraturan Presiden RI No. 42 Tahun 2013 Tentang Gerakan Nasional Percepatan Perbaikan Gizi. Jakarta: Kementerian Kesehatan Republik Indonesia; 2013.

2. Barker DJ, Gelow J, Thornburg K, Osmond C, Kajantie E, Eriksson JG. The early origins of chronic heart failure: Impaired placental growth and initiation of insulin resistance in childhood. Eur J Heart Fail. 2010;12(8):819-25. https://doi.org/10.1093/ eurjhf/hfq069

PMid:20504866

3. Soewondo P, Laurentius P. Prevalence, characteristics, and predictors of pre-diabetes in Indonesia. $\mathrm{J}$ Med. 2011;20(4):283-94

4. Tahir M, Hikmah N, Rahmawati R. Analisis kandungan Vitamin C dan $\beta$-karoten dalam daun kelor (Moringa oleifera Lam.) dengan metode spektrofotometri UV-vis. J Fitofarmaka Indones. 2016;3(1):135-40. https://doi.org/10.33096/jffi.v3i1.173

5. Tekle A, Belay A, Kelem K, Yohannes M, Wodajo B, Tesfaye Y. Nutritional profile of Moringa stenopetala species samples collected from different places in Ethiopia. Eur J Nutr Food Saf 2015;5(5):1100-1. https://doi.org/10.9734/ejnfs/2015/21263

6. Aminah $\mathrm{S}$, Tezar R, Mufihani Y. Kandungan nutrisi dan sifat fungsional tanaman kelor (Moringa oleifera). Bul Pertanian Perkotaan. 2015;5(2):35-44

7. Bogdanov S, Jurendic T, Sieber R, Gallmann P. Honey for nutrition and health: A review. J Am Coll Nutr. 2008;27(6):67789. https://doi.org/10.1080/07315724.2008.10719745 PMid:19155427

8. Odedele L, Ajao F, Yusuf J, Adu F. Effect of aqueous moringa seed extract on oxidative stress in alloxan-induced gestational diabetic rats. Med Res Arch. 2017;5(9):1-14.

9. Khuzaimah A, Hadju V, Asad S, Abdullah N, Bahar B, Riu D. Effect of honey and Moringa oleifera leaft extract supplementation for preventing DNA damage in passive smoking pregnancy. Int $J$ Sci. 2015;24(1):138-45.

10. Rismunandar R. Berwiraswasta Dengan Beternak Lebah. Bandung: Sinar Baru; 1996.

11. Varney H, Kriebs J, Carolyn L, Esty W, Laily M, Gita T. Buku Asuhan Kebidanan. Jakarta: EGC; 2007.

12. Herrera E, Muñoz C, López-Luna P, Ramos P. Carbohydratelipid interactions during gestation and their control by insulin. Braz J Med Biol Res. 1994;27(11):2499-519.

PMid:7549970

13. Herrera E. Metabolic adaptations in pregnancy and their implications for the availability of substrates to the fetus. 
Eur J Clin Nutr. 2000;54(1):S47-51. https://doi.org/10.1038/ sj.ejcn. 1600984

PMid:10805038

14. Vadakekut E, McCoy S, Payton M. Association of maternal hypoglycemia with low birth weight and low placental weight: A retrospective investigation. J Am Osteopath Assoc. 2011;111(3):148-52.

PMid:21464263

15. Reddi A, Oppermann W, Strugatz L, Cole H, CameriniDavolos R. Effect of pregnancy on serum alanine concentration in normal and genetically diabetic mice. Horm Metab Res. 1976;8(6):478-82. https://doi.org/10.1055/s-0028-1093600 PMid:1002107

16. Wolfensohn S, Lloyd M. Handbook of Laboratory Animal Management and Welfare. $4^{\text {th }}$ ed. America: Wiley-Blackwell; 2013.

17. Erejuwa OO, Ezeokpo BC, Nwobodo NN, Asika EC, Nwadike KI, Uwaezuoke $\mathrm{NI}$, et al. Effect of honey on body weight, body mass index and adiposity in high-fat diet fed wistar rats. EC Pharmacol Toxicol. 2017;3(1):3-12. https://doi.org/10.1515/ jbcpp-2019-0151

18. Al-Waili NS. Natural honey lowers plasma glucose, C-reactive protein, homocysteine, and blood lipids in healthy, diabetic, and hyperlipidemic subjects: Comparison with dextrose and sucrose. J Med Food. 2004;7(1):100-7. https://doi. org/10.1089/109662004322984789

PMid:15117561

19. Bantle JP. Dietary fructose and metabolic syndrome and diabetes. J Nutr. 2009;139(6):1263S-8S. https://doi.org/10.3945/ jn. 108.098020

PMid:19403723

20. Kaneto H, Katakami N, Matsuhisa M, Matsuoka TA. Role of reactive oxygen species in the progression of type 2 diabetes and atherosclerosis. Mediators Inflamm. 2010;2010:1-11. https://doi.org/10.1155/2010/453892

PMid:20182627
21. Oran J. Flavonoid inhibition of sodium-dependent Vitamin C transporter 1 (SVCT1) and glucose transporter isoform 2 (GLUT2), intestinal transporters for Vitamin C and glucose. J Biol Chem. 2007;277(18):15252-60. https://doi.org/10.1074/jbc. m110496200

\section{PMid:11834736}

22. Barbosa DS. Green tea polyphenolic compounds and human health. J Verbrauch Lebensm. 2007;2(4):407-13.

23. Evans JL, Goldfine ID, Maddux BA, Grodsky GM. Are oxidative stress-activated signaling pathways mediators of insulin resistance and beta-cell dysfunction? Diabetes. 2003;52(1):1-8. https://doi.org/10.2337/diabetes.52.1.1

PMid:12502486

24. Kaneto H, Kajimoto $Y$, Miyagawa JI, Matsuoka TA, Fujitani $Y$ Umayahara $\mathrm{Y}$, et al. Beneficial effects of antioxidants in diabetes: Possible protection of pancreatic beta-cells against glucose toxicity. Diabetes. 1999;48(12):2398-406. https://doi. org/10.2337/diabetes.48.12.2398

\section{PMid:10580429}

25. Mallongi A, Novitasari DA, Noor NB, Fatmawati F, Saleh M Nur R. Health risk analysis of phenol and arsenic exposure among kokoda communities village Sorong, West Papua. Enferm Clín. 2020;30(4):123-6. https://doi.org/10.1016/j. enfcli.2019.10.055 PMid:32545028

26. Mallongi A, Stang S, Syamsuar S, Natsir MF, Astuti RD, RaufAU, et al. Potential ecological risks of mercury contamination along communities area in tonasa cement industry Pangkep, Indonesia. Enferm Clín. 2020;30(4):119-22. https://doi. org/10.1016/j.enfcli.2019.10.054

27. Zakaria Z, Hadju V, As'ad S, Bahar B. Pengaruh pemberian ekstrak daun kelor terhadap kuantitas dan kualitas air susu ibu (asi) padaibu menyusui bayi 0-6 bulan. Med Kesehatan Masyarakat Indones. 2016;12(3):161-9. https://doi. org/10.33024/manuju.v2i3.1677 